\title{
RANCANGAN DESAIN PRODUK RAK POT BUNGA DENGAN PENDEKATAN 7 LANGKAH NIGEL CROSS
}

\author{
Wakhit Ahmad Fahrudin \\ Dosen Teknik Industri Universitas Pamulang \\ dosen01310@unpam.ac.id
}

\begin{abstract}
ABSTRAK
Dunia mainan memang banyak diminati oleh kalangan anak kecil sampai orang dewasa. Keunikan berdasarkan desain produk akan menjadi sebuah daya tarik tersendiri dari produk tersebut. Penelitian ini memiliki tujuan untuk merancang dan mengembangkan sebuah produk yang selama ini masih mencontoh beberapa desain dari luar negeri yang terkadang sudah mempunyai hak paten sehingga harus membayar royalti jika ingin menggunakan desain tersebut. Perancangan desain ini timbul karena adanya kesempatan untuk di pasarkan karena dari beberapa desain dibuat dalam bentuk yang berbeda beda dan terkesan unik. Setelah membuat rangkaian yang dibutuhkan konsumen dalam pembuatan sepsifikasi produk baru kemudian ditetapkan pencapaian dengan kebutuhan konsumen dari produk yang dibuat, kemudian dievaluaisi dan dipilih untuk diproduksi. Setelah desain dari permainan tersebut selesai dibuatlah analisis dengan menggunakan SWOT dalam menentukan menentukan kekuatan dan kelemahan dari desain mainan tersebut. Hasil dari penelitian ini desain produk mainan dapat diproduksi secara masal dengan desain yang inovasi diminati pelanggan dan memliliki beberapa fungsi dan keunggulan diantaranya sebagai hiasan dan menanam tanaman hiasan didepan rumah, kantor, sekolahan dan lain-lainya dengan lahan yang sempit dan mudah dipindah-pindahkan sesuai dengan keinginan. Tetapi selain dari kekuatan desain ini ada kelemahan salah satunya adalah hanya dapat menanam tanaman hias atau pohon sesuai dengan ukuran pot bunga pada tangkai tiang penyangganya. Peluang dari pemilihan desain ini adalah bahan baku mudah didapat dengan memanfaatkan bekas besi behel coran yang sudah tidak dipakai. Untuk ancamanya dalam pemilihan desain ini adalah pengrajin pembuatan mainan akan bermunculan karena sangat mudah dicontoh dan mudah dalam proses pembuatanya.
\end{abstract}

Kata Kunci : Desain Produk, 7 Nigel Cross, SWOT

\section{PENDAHULUAN}

Begitu banyak sekali desain produk dalam beberapa jenis namun tidak sesuai dengan keinginan terhadap konsumen. Dalam kehidupan sehari hari selalu berinteraksi antar sesama manusia, hewan dan tumbuhan sebagai perjalanan kehidupan. Upaya dalam interaksi manusia ini sangatlah luas dan beberapa tempat seperti rumah, sekolahan, kantor-kantor tempat umum dan lain sebagainya merupakan lingkungan setiap yang setiap harinya kita jalani kehidupan.

Jika kita amati lebih lanjut untuk meciptakan suasana yang indah, nyaman, tenang sering kali desain rumah dibuatlah tanaman didepan rumah seperti bunga-bunga, dan tanaman hias lainya. Hal ini dimaksudkan salah satunya adalah untuk menciptakan keindahan dan kenyamanan di luar rumah maupun didalam rumah. Banyak juga dari beberapa orang memilih membeli rak pot bunga sebagai sarana meletakan beberapa tanaman sebagai hiasan di dalam maupun diluar rumah. Salah satu contohnya adalah ketika kita berhubungan dengan beberapa teman atau kerabat, kita akan bertamu dirumahnya sering melihat beberapa pot bunga yang diletakan dalam depan rumah, samping rumah bahkan ada di dalam rumah sebagai hiasan agar rumah kelihatan tampak indah dan nyaman. Selain dilihat indah dan nyaman beberapa fungsi meletakan tanaman hias atau tanaman lainya adalah menambah suasana yang sejuk dengan udara dipagi hari.

Melihat dari beberapa bangunan rumah, perkantoran maupun gedung fasilitas umum sering mempunyai lahan ukuran kecil sehingga keinginan untuk menanam tanaman bunga sudah tidak ada lahanya. Selain daripada itu 
beberapa desain bangunan terkadang tidak mempertimbangkan dengan suasana yang sejuk penuh dengan tanaman untuk itu dalam penelitian ini membuat usulan desain rak pot bunga yang dapat dipindah-pindakan tempat sesuai dengan yang diinginkan. Pertimbangan untuk membuat rak pot bunga dapat dinilai berdasarkan nilai estetika dalam bentuk wujud dan warna, selain itu desain produk dapat dilihat berdasarakan fungsi dan kenyamanan. Untuk itu penelitian ini memberikan sebuah gambaran yang merujuk pada inovasi melalui ceklist pengguna atau pelanggan langsung, sehingga harapanya desain yang akan dibuat produk sesuai dengan permintaan konsumen.

\section{DASAR TEORI}

\section{A. Definisin Desain Produk}

Penjelasan mengenai desain produk adalah sebuah cara untuk mendapatkan bentuk benda kerja seperti peralatan elektronik, furniture, alat olah raga, transportasi, mainan, dan masih banyak lagi. Pendapat Porter tentang desain produk adalah sebuah gambaran proses rencana pembuatan produk yang berfokus pada fungsi dan penampilan produk yang didapat dari keinginan konsumen langsung, (Kotler, 2005)

Dalam desain produk memfokuskan pada pemakai atau konsumen dan produk sebagai benda yang dipakai dalam tujuan tertentu. Hubungan terhadap timbal balik memfokuskan pada beberapa aspek teknis, fungsi, kegunaan, dan tujuan dari desain itu dibuat, sehingga dalam perencanaan dan pengembangan suatu produk yang di desain memperhatikan dari bahan, kemampuan proses produksi, kebutuhan pasar dan ditlihat berdasarkan sosial budaya ekonomi.

Penetapan ukuran-ukuran yang menjadi acuan desain produk oleh seorang engineer atau perancang, spesifikasi produk akan membatasi meluasnya desain yang akan dibuat. Karena dalam merancang desain akan berdampak pada ide dan rancanganya sedikit dan tidak berkembang dalam melakukakan rancangan desain. Selain daripada itu, jika terlalu luas juga akan berpengaruh pada solusi atau hasil yang tidak maksimal. Dalam desain produk disamping memiliki beberapa karakteristik seperti fungsi teknis, ekonomis, atau sekedar pemenuhan kebutuhan fisik saja, namun di harapakan juga dapat memberikan sebuah fungsi simbolik, kenyamanan, keindahan, dalam produk yang diproduksi masal.

\section{B. Teori Nigel Cross}

Penerapan perancagnan desain produk dengan menggunakan pendekatan Nigel Cross mempunyai beberapa langkah yang harus dilalui diantaranya adalah sebagai berikut:

1. Klassifikasi Tujuan Produk

Pada tahap ini dalam menentukan rancagan sebuah desain dengan menjabarkan terkait dari tujuan desain itu dibuat. Salah satu tools untuk merinci dari tujuan dibuat rancangan desain adalah dengan pohon tujuan atau sering disebut degan (Objective Trees). Dari analisis menggunakan pohon tujuan akan didapat identifikasi tujuan dan sub tujuan mengenai rancangan produk yang dan beserta keterkaitan antara keduanya yaitu dibentuk dalam sebuah diagram yang menunjukan hubungan arahanya antara tujuan dan sub tujuan. Dengan melihat percabangan pada pohon tujuan maka didapat hasil tujuan dari pencapaian tujuan tertentu. Berikut adalah langkah-langkah dalam membuat klasifikasi tujuan diantaranya

a. Membuat sebuah daftar yang isinya adalah tujuan dari perancangan desain produk tersebut.

b. Menyusun daftar dari perancangan desain produk dengan level paling atas ke level paling bawah.

c. Menggambarkan diagram pohon tujuan sesuai dengan hubungan-hubungan yang menunjukan kecocokan atau kesamaan desain.

2. Menetapkan Fungsi Desain Produk Berdasarkan metode Objective Trees dapat melihat permasalahan dan perbedaan dari beberapa tingkatan secara terperinci. Dalam perancangan dapat menaikan maupun menurunkan dari tingkatan permasalahan pada analisis dengan metode tersebut.

3. Menetapkan Kebutuhan Desain Produk.

Penetapan kebutuhan desain dilakukan setelah menetapkan fungsi desain produk yang dilanjutkan dengan menetapkan kebutuhan fungsi produk. Tujuan dari penetapan kebutuhan desain produk adalah merinci dari semua kebutuhan sesuai dengan spesifikasi dalam proses pembuatanya sehingga lebih akurat dalam mendesain produk atau merancang sebuah produk. Menentukan kebutuhan dalam 
merancamg suatu produk seorang engineer harus mengetahui batasan-batasan mengenai apa saja yang herus diraih dalam spesifikasi, performansi dengan membatasi solusi yang akan diterima. Sehingga sepesifikasi tersebut tidak meluas dan mengarah pada solusi yang kurang tepat.

4. Menentukan Karakteristik Desain Produk Cara untuk menentukan karakteristik desain produk dengan pendekatan Nigel Cross adalah menggunkan Quality Function Develoyment yang sering disingkat dengan QFD. Metode QDF ini dikembangkan oleh Yoji Akao tahun 1966 di Jepang. Jadi QFD adalah salah satu metode yang menterjemahkan permintaan konsumen terhadap desain produk dengan mengedepankan kualitas desain yang mempunyai tujuan untuk kepuasan pelanggan dan menyesuaikan dengan permintaan sepesifikasi yang diberikan konsumen hingga sampai ke tahap produksi. Selain itu QFD sebagai cara untuk menjamin kualitas desain produk.

5. Pembangkitan Karakteristik

Maksud dari pembangkitan karakteristik ini adalah merancang segala permasalahan dalam membangkitkan alternatif-alternatif yang dapat mencapai solusi dari permasalahan tersebut. Secara sistematis perubahan bentuk untuk mengetahui produk yang dibuat dapat digunakan metode Morphological Chart. Produk-produk yang berbeda atau berfariasi dibuat dalam chart ini dari berbagai kombinasi dari kemungkinan yang terjadi. Dalam Morphological chart terdapat komponen, sub solusi dan bagian dari elemen dikombinasikan.

6. Evaluasi Alternatif

Dalam evaluasi ini menggunkan penentuan alternatif yang dapat memenuhi kebutuhan konsumen dengan penentuan alternatif terbaik hingga berbagai alternatif yang muncul. Berikut adalah urutan-urutan dalam mengevaluasi alternatif.

a. Membuat daftar tujuan desain produk.

Dengan menggunakan pohon tujuan, RCA atau fishbone.

b. Penyusunan format daftar tujuan dan sub tujuan mulai tingkatan yang tinggi menuju tingkatan yang lebih rendah. Dapat menggunakan metode weighted objective c. Membuat Pembobotan

Dalam pembuatan pembobotan disini adalah membuat bobot yang relatif dari setiap tujuanya. Dapat menggunakan perbedaan nilai pada setiap pohon tujuan sampai jumlah total bobot bernilai 1 .

d. Menentukan nilai parameter pelaksanaan dari kegunaan masingmasing tujuan. Dapat dilihat dari tujuan kualitatif atau kuantitatif dan dibuatkan dalam skala yang lebih sederhana.

e. Perbadingan nilai dan menghitung nilai relatif pada setiap alternatif perancangan. Dengan bobot nilai dikalikan setiap skor. Perbandingan dan analisis dalam penilaian alternatif jumlah nilai terbesar dan terbaik hanyalah untuk sekedar pemilihan nilai.

f. Rincian perbaikan.

Untuk mewujudkan rancangan produk tidak diwujudkan dengan kreasi atau atas konsep perancangan baru principle dengan memodifikasi dan mengembangkan produk dalam meningkatkan tampilan, mengurangi berat, meninggikan daya tariknya. Jadi terdapat dua jenis dalam principle, yang pertama adalah untuk meningkatkan nilai produk dan yang kedua adalah mengurangi biaya produksi.

\section{Analisa SWOT}

Analisis SWOT adalah teknik untuk menilai kinerja, persaingan, risiko, dan potensi bisnis, serta bagian dari bisnis seperti lini produk atau divisi, industri, atau entitas lainnya (Rangkuti, 2011).

Analis menyajikan analisis SWOT sebagai kotak dengan masing-masing dari empat area membentuk satu kuadran. Pengaturan visual ini memberikan gambaran singkat tentang posisi perusahaan. Meskipun semua poin di bawah judul tertentu mungkin tidak sama pentingnya, mereka semua harus mewakili wawasan utama ke dalam keseimbangan peluang dan ancaman, keuntungan dan kerugian, dan sebagainya.

Dari beberapa pengertian diatas, penulis dapat mengambil kesimpulan bahwa analisis SWOT merupakan salah satu metode untuk menggambarkan kondisi dan mengevaluasi suatu masalah, proyek atau konsep bisnis yang berdasarkan faktor eksternal dan faktor internal 
yaitu strength, opportunities, weaknesesses, threats. Analisis SWOT merupakan singkatan dari strength, opportunities, weaknesesses, threats dimana penjelasannya sebagai berikut:

1. Kekuatan (Strenght)

Dari analisis kekuatan ini adalah keunggulan daripada desain produk yang dibuat sehingga menampilkan dari segi desain yang menjadi kekuatan daripada produk lainya.

2. Kelemahan (Weakness)

Analisis kelemahan dalam hal ini adalah menampilkan beberapa kekurangan dari desain produk yang akan dibuat sehingga mengetahui beberapa variabel yang harus diperbaiki dari desain tersebut.

3. Peluang (Opportunities)

Dalam analisis peluang merupakan kesempatan dalam produk yang akan dibuat melalui desain tersebut sehingga ketika akan diproduksi akan mengetahui peluang dari desain yang dibuat sehingga menjadikan ukuran dalam memproduksinya.

4. Ancaman (Threat)

Ancaman adalah rintangan-rintangan utama bagi posisi sekarang atau yang diinginkan dari perusahaan. Masuknya pesaing baru, perumbuhan pasar yang lambat, daya tawar pembeli dan pemasok utama yang meningkat, perubahan teknologi, dan peraturan yang baru atau yang direvisi dapat merupakan ancaman bagi keberhasilan suatu perusahaan.

\section{METODE DAN TEKNIK PENGUKURAN}

Dalam metode dan teknik pengukuran dapat dijelaskan berikut:

\section{A. Jenis Penelitian}

Dalam melakukan penelitian ini, jenis metode penelitian yang digunakan adalah sebagai berikut:

1. Metode Analisis, yang terdiri dari:

a. Metode Deskriptif

Metode ini menggambarkan data masalah yang ada dan berkembang pada saat penelitian dilakukan (data aktual yang kemudian dianalisis untuk menguji hipotesis yang telah dilakukan) melihat keadaan serta mengumpulkan beberapa data berdasarkan fakta-fakta yang ada diperusahaan.

\section{b. Metode Historis}

Mengumpulkan data perusahaan pada masa kini dan masa lalu untuk mengetahui perkembangan perusahaan.

2. Teknik Pengolahan Data

Teknik Pengolahan data pada penelitian ini adalah dengan menggunakan teknik pengolahan data secara kuantitatif yang merupakan pengolahan data secara perhitungan, dimana data-data yang disajikan berupa angka.

\section{B. Data dan Sumber Data}

Data dan sumber data adalah segala sesuatu yang dapat memberikan informasi mengenai data. Berdasarkan sumbernya data dibedakan menjadi 2 yaitu:

1. Data Primer

Data primer merupakan data yang didapatkan langsung dari sumbernya, diamati dan dicatat untuk pertama kalinya.

2. Data Sekunder

Data sekunder merupakan kumpulan data yang diperoleh dengan cara hasil studi keperpustakaan. Studi keperpustakaan ini dilakukan untuk mendapatkan dasar pemikiran, konsep atau landasan teori dari literatur-literatur yang semuanya berfungsi sebagai pengontrol jalannya penelitian, sebagai bahan perbandingan dan panduan dalam pemecahan masalah.

\section{Teknik Pengumpulan Data}

Teknik pengumpulan data yang dilakukan dalam penelitian ini terdiri dari:

1. Observasi Lapangan

Teknik ini merupakan pengumpulan data dengan cara turun langsung ke lapangan dengan tujuan mendapatkan data aktual yang diperlukan.

2. Wawancara

Wawancara adalah teknik pengumpulan data dengan cara wawancara langsung dengan narasumber yang mempunyai keterkaitan dengan penelitian ini untuk mendapatkan data yang lebih akurat.

3. Dokumentasi

Dokumentasi merupakan data dari dokumen, catatan, atau arsip perusahaan yang diambil dari penelitian.

Metode penelitian menunjukan bagaimana penelitian dilakukan dari identifikasi masalah sampai dengan analisis dan kesimpulan. Langkah awal dalam 
penelitian ini adalah melakukan pengumpulan data. Data yang dikumpulkan merupakan data hasil kuesioner dan wawancara. Data yang dikumpulkan selanjutnya diolah dengan melakukan pengujian statistik meliputi: pengujian kenormalan data, pengujian keseragaman data, pengujian kecukupan data, perhitungan persentil. Kemudian dengan memperhatikan konsep perancangan produk dilakukan perancangan mainan dengan menyesuaikan dengan data yang digunakan.

Tahapan metode dari penelitian ditunjukan pada Gambar 3.1 berikut ini:

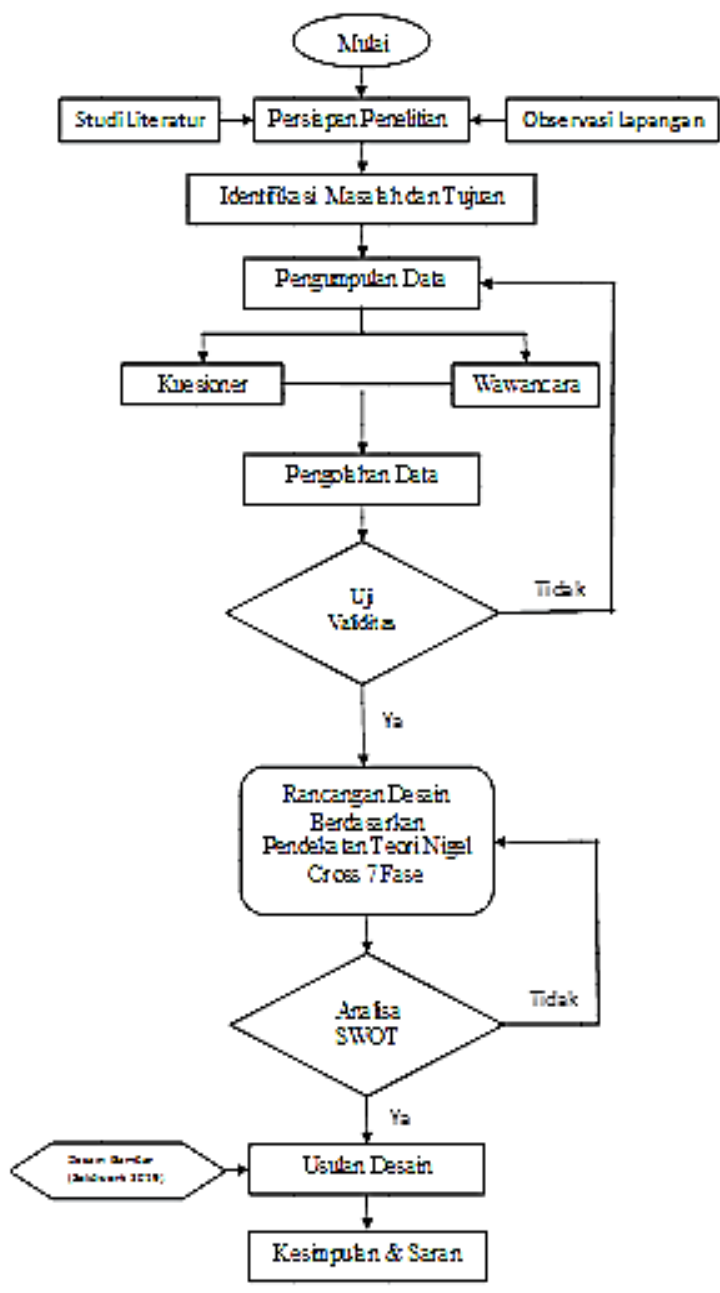

(Gambar 3.1 Flowchart)

Untuk langkah terakhir adalah melakukan analisis terhadap hasil rancangan, dimana pada tahap ini dilakukan pembandingan antara alat yang dirancang dengan alat yang sudah ada dengan menggunakan pendekatan 7 Langkah Nigel Cross.
Tabel 1. Tahapan perancangan Nigel Croos

\begin{tabular}{|c|c|c|c|}
\hline No. & $\begin{array}{c}\text { Tahapan dalam } \\
\text { proses perancangan }\end{array}$ & $\begin{array}{l}\text { Metode yang } \\
\text { relevan }\end{array}$ & Tujuan \\
\hline 1. & $\begin{array}{l}\text { Klasifikasi tujuan } \\
\text { (Clarifying Object) }\end{array}$ & Objectives Trees & $\begin{array}{l}\text { Untuk mengklarifikasin tujuan-tujuan dari } \\
\text { sub perancangan serta hubungannya satu } \\
\text { sama lain. }\end{array}$ \\
\hline 2. & $\begin{array}{l}\text { Penetapan fungsi } \\
\text { (Establishing } \\
\text { Function) }\end{array}$ & Function Analysis & $\begin{array}{l}\text { Untuk menentukan fungsi-fungsi yang } \\
\text { diperlukan dan batas-batas sistem } \\
\text { rancangan produk baru. }\end{array}$ \\
\hline 3. & $\begin{array}{l}\text { Menyusun } \\
\text { Kebutuhan (Setting } \\
\text { Requirement) }\end{array}$ & $\begin{array}{l}\text { Performances } \\
\text { Specification }\end{array}$ & $\begin{array}{l}\text { Untuk membuat spesifikasi kinerja yang } \\
\text { akurat dari suatu solusi rancangan yang } \\
\text { diperlukan. }\end{array}$ \\
\hline 4. & $\begin{array}{l}\text { Penentuan } \\
\text { Karakteristik } \\
\text { (Determining } \\
\text { Characteristic) }\end{array}$ & Quality Function & $\begin{array}{l}\text { Untuk menetapkan target yang akan dicapai } \\
\text { oleh karakteristik teknik produk sehingga } \\
\text { dapat mewujudkan kebutuhan konsumen. }\end{array}$ \\
\hline 5. & $\begin{array}{l}\text { Penentuan Alternatif } \\
\text { (Generating } \\
\text { Alternatif) }\end{array}$ & $\begin{array}{l}\text { Morphological } \\
\text { Chart }\end{array}$ & $\begin{array}{l}\text { Untuk menetapkan serangkaian alternatif } \\
\text { solusi perancangan lengkap untuk suatu } \\
\text { produk dan memperluas pencarian solusi } \\
\text { baru yang potensial }\end{array}$ \\
\hline 6. & $\begin{array}{l}\text { Evaluasi Alternatif } \\
\text { (Evaluating } \\
\text { Alternatif) }\end{array}$ & $\begin{array}{c}\text { Weighted } \\
\text { Objectives } \\
\text { (Beban Obyektif) }\end{array}$ & $\begin{array}{l}\text { Untuk membandingkan nilai utilitas dari } \\
\text { proposal alternatif rancangan berdasarkan } \\
\text { performansi dan pembobotan yang berbeda. }\end{array}$ \\
\hline 7. & Komunikasi- & Value & Intuk meninokatkan dan mempertahankan \\
\hline & (Improving & $\Theta \oplus 114 \%$ & 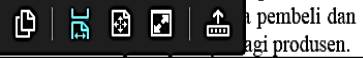 \\
\hline
\end{tabular}

Dari ketujuh langkah Nigel Cross tersebut akan dihubungkan dengan analisa SWOT sebagai rangkaian dari usulan desain yang akan dibuat dalam membuat produk mainan.

\section{HASIL DAN PEMBAHASAN}

\section{A. Ditinjau Berdasarkan Kasifikasi Tujuan}

Klasifikasi produk dengan hasil Brainstorming melibatkan penulis dan tim, sehingga dapat dibuat diagram tree sebagai berikut:

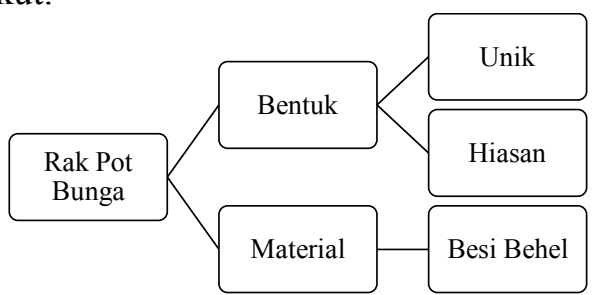

Dari hasil klasifikasi tujuan diusulkan bahwa contoh rancangan desain mainan dapat dilihat pada gambar-gambar dibawah ini:

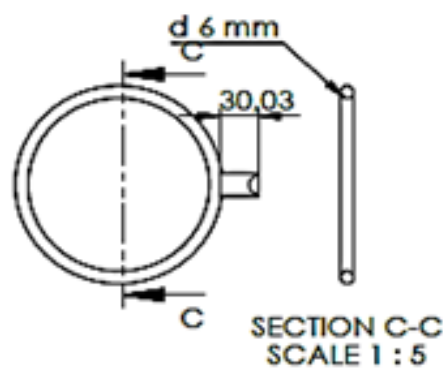

Gambar 4.1 Kerangka Pot 
Dalam desain kerangka pot ini berguna untuk menopang dari jenis pot dengan diameter $90 \mathrm{~mm}$.

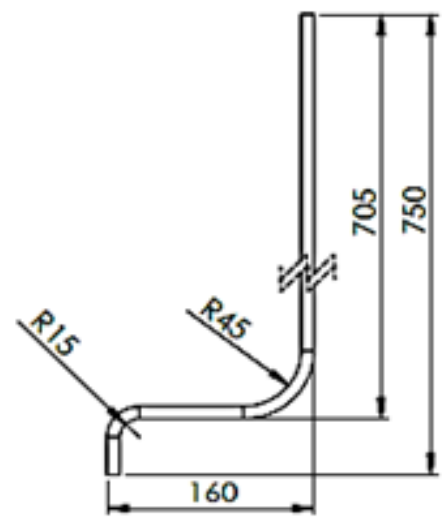

Gambar 4.2 Tiang Penyangga

Pada tiang penyangga ini diperoleh dengan tinggi $750 \mathrm{~mm}$. Dengan lebar $160 \mathrm{~mm}$, ini terdiri dari 3 jumlah tiang.

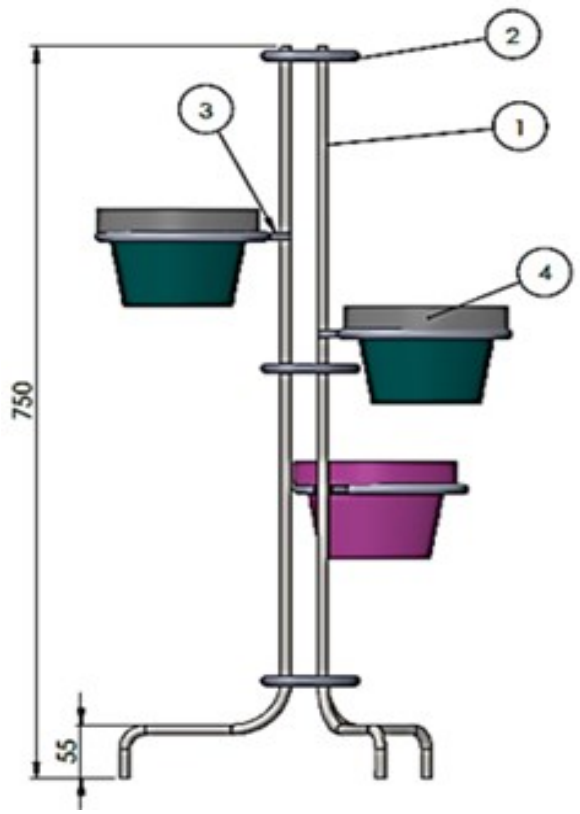

Gambar 4.3 Gambar Assembly Rak Pot

Pada gambar assembly rak pot terdiri dari 4 komponen yaitu

1. Tiang yang terdiri dari 3 buah

2. Pengikat tiang yang terdiri dari 3 buah

3. Kerangka pot yang terdiri dari 3 buah

4. Pot yang terdiri dari 3 buah

Dari desain gambar diatas merupakan contoh produk yang akan dibuatkan desain sebagai acuan dalam mendesain produk pembuatan kerangka pot bunga. Hasil gambar ini menggunakan Sofware Solidwork 2019 dari beberapa part kemudian digabungkan menjadi satu. Untuk detailnya dapat dilihat pada gambar assembly diatas.

\section{A. Penetapan Fungsi}

Untuk pemilihan desain produk Pot Bunga Dengan cara pemilihan Boundary System yang diberikan pada penetapan sebagai fungsi sehingga dapat dilihat pada gambar berikut:

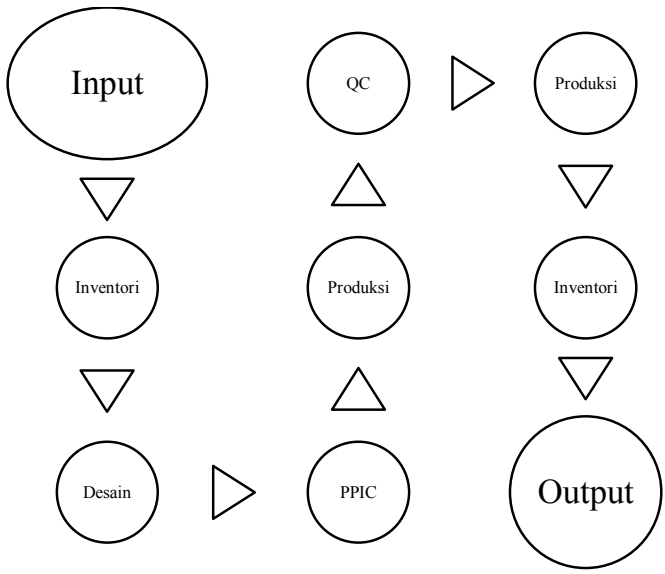

Gambar 4.3 Alur Fungsi Penetapan

\section{B. Kesesuaian Kebutuhan}

Perancangan dalam kesesuaian kebutuhan dapat ditetapkan desain terhadap konsumen apa yang akan diinginkan konsumen dengan produk yang dirancang. $\mathrm{D}$ adalah permintaan konsumen berdasarkan atau sesuai dengan desain rancangan dan $\mathrm{W}$ adalah keseuaian dengan harapan konsumen.

Tabel 4.1 Penetapan Kebutuhan

\begin{tabular}{|c|l|}
\hline D atau W & \multicolumn{1}{|c|}{ Usulan } \\
\hline W & Bentuk miniatur transportasi \\
\hline W & Material dari kayu \\
\hline W & Beberapa Part \\
\hline W & Proses assembly \\
\hline K & Dapat dimainkan \\
\hline K & Dapat sebagai hiasan \\
\hline K & Dapat sebagai asbak \\
\hline K & Daya tahan produk \\
\hline K & Wama produk \\
\hline K & Harga produk \\
\hline
\end{tabular}

\section{Karakteristik Produk}

Mencari karakteristik produk sesuai permintaan dapat menganalisa dengan HOQ. Permintaan konsumen terhadap desain produk dengan mengedepankan kualitas desain yang mempunyai tujuan untuk kepuasan pelanggan dan menyesuaikan dengan permintaan 
sepesifikasi yang diberikan konsumen hingga sampai ke tahap produksi.
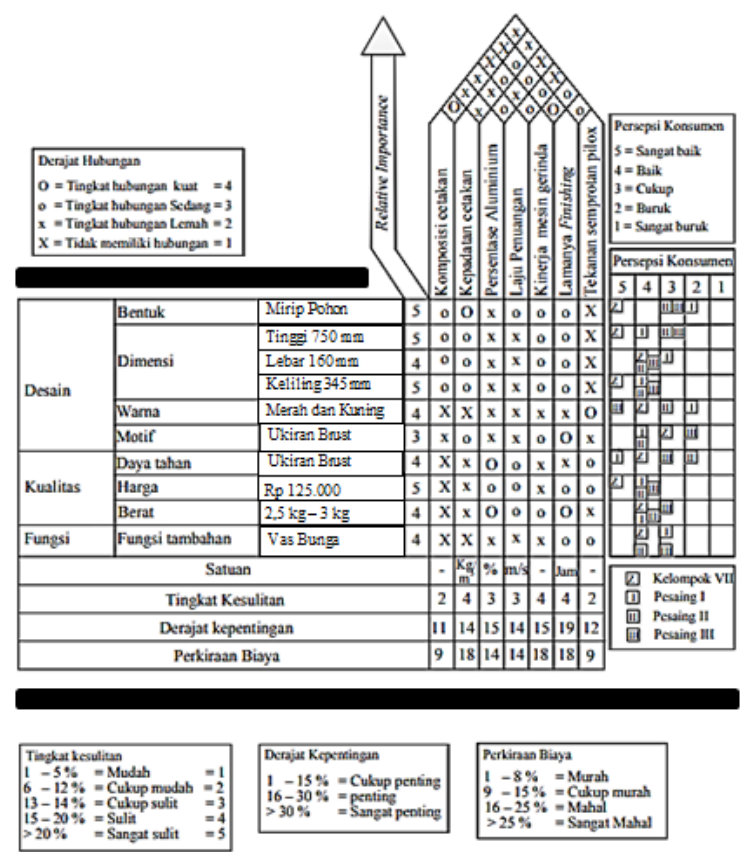

Gambar 4.4 House Of Quality

\section{Menggunakan Pembangkitan Alternatif}

Dengan menggunakan alternatif ini merupakan sebuah Morphology Chart terhadap produk tempat Pot bunga dapat dilihat berikut:

Tabel 2. Morphologycal Chart

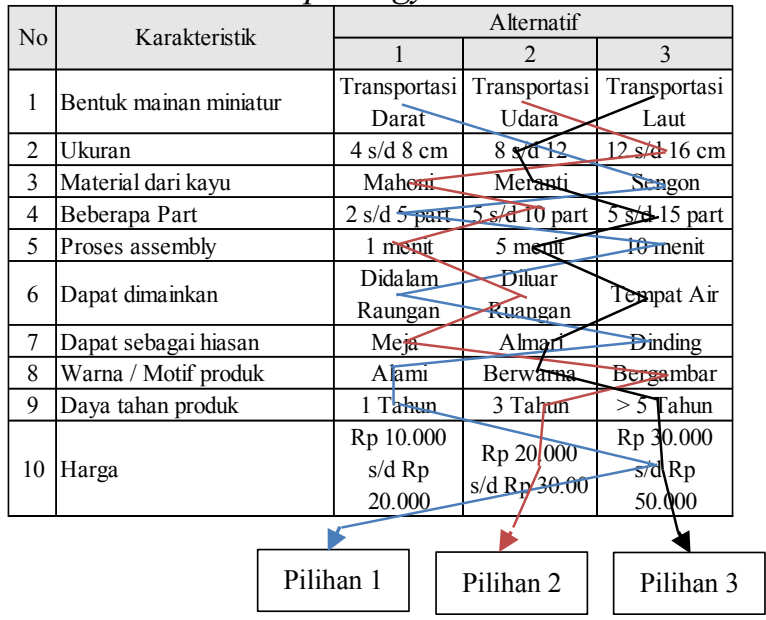

Produk yang akan diproduksi dengan memiliki jumlah dengan alternatif pada morphological chart dengan sejumlah tiga alternatif dan mempunyai sepuluh atribut dengan rumus kombinasi sebagai berikut:

1. Total Kombinasi $=\mathrm{n} \mathrm{C}^{\mathrm{r}}$

2. Total Kombinasi $=3 \mathrm{C}^{1}$

Sehingga didapat jumlah sebagai berikut:

1. Total Kombinasi

$$
3 \times 3 \times 3 \times 3 \times 3 \times 3 \times 3 \times 3 \times 3=(3)^{10}
$$

Jadi jumlah kombinasi ada

$=59049$

Sehingga dalam jumlah kombinasi alternatif mencapai sebanyak 59049 cara.

Dalam analisa evaluasi dengan alternatif dapat menggunakan gant chart terhadap produk yang dibuat desain pot bunga sehinggan dengan menggunkan AHP. Untuk lebih jelasnya dapat dilihat gan chart produk miniatur berikut:

\section{E. Evaluasi Alternatif}

Bagian ini cara analisa menggukakan pendekatan AHP. Sehingga dapat menetapkan produk pot bunga dan dapat dilihat Gant Chart berikut:

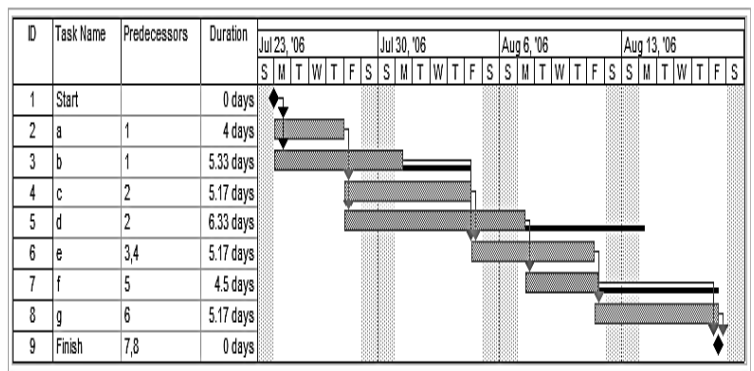

Gambar 4.5 Gant Chart

\begin{tabular}{|l|lr} 
A. Analisa SWOT & $\begin{array}{r}\text { Dari } \\
\text { pemilihan } \\
\text { didapat }\end{array}$ & $\begin{array}{r}\text { analisa } \\
\text { desain } \\
\text { dengan }\end{array}$
\end{tabular}
menggunakan analisa SWOT berikut ini:

A. Strength

Dalam analisa kekuatan desain produk rak pot disebutkan sebagai berikut:

1. Bentuknya yang unik dan mudah dalam proses pembuatanya.

2. Belum ada produk rak pot bunga sebelumnya.

3. Bahan baku yang mudah didapat untuk memproduksinya.

4. Dapat dipindah-pindah sesuai dengan keinginan.

\section{B. Weakness}

Dari hasil analisa kelemahan dari desain ini adalah

1. Hanya mampu menampung 3 pot bunga saja.

2. Mudah untuk dicontoh dalam proses pembuatanya.

3. Pilihan pot hanya yang berdiameter $90 \mathrm{~mm}$ saja. 
4. Mudah terjatuh / roboh jika terlalu terkena benturan kencang.

\section{Opportunities}

Peluang yang didapat dalam rancangan desain pot bunga ini adalah

1. Banyaknya rumah-rumah yang minimalis sehingga tidak ada celah dalam menanam bunga.

2. Sebagai sarana penghijauan di kantorkantor maupun ditempat umum.

3. Bahan baku mudah didapat sehingga peluang bagi yang ingin memproduksinya.

4. Harga yang terjangkau untuk produk rak pot yang baru

\section{Threat}

\section{Terakhir adalah hambatan}

1. Akan muncul produk sejenis di pasaran.

2. Orang tua dan pendamping malas untuk berperan dalam proses pengenalan makanan dan fungsinya pada anak dan cenderung cuek.

3. Karakter dan kepribadian anak yang berbeda-beda, ada anak yang sangat aktif, tetapi juga ada anak yang malas-malasan, sehingga menghambat jalannya permainan.

\section{KESIMPULAN}

Berdasarkan perumusan masalah rancangan desain produk mainan anak dapat dibuat dengan kriteria seperti berikut:

1. Pemilihan untuk usulan desain dalam membuat mainan miniatur bentuk miniatur transportasi, material dari kayu, terdiri dari beberapa part, proses assembly, dapat sebagai mainan dan dapat dapat juga sebagai hiasan, dapat sebagai asbak, dan untuk warna ada beberara motif yang bergambar, motif alami, dan motif berwarna.

2. Pemilihan untuk alternatif desain ditentukan tema yaitu transportasi, yang terdiri dari transportasi darat seperti contoh mobil, truk, becak. Untuk trasportasi udara seperti holicopter dan pesawat. Untuk transportasi laut dicontohkan kapal, seperti kapal nelayan maupun pasar pesiar.
3. Hasil dalam analisa SWOT memperoleh kekuatan dalam desain mainan miniatur ini adalah dapat dimaikan atau digunakan sebagai mainan maupun hiasan dari usia anak anak hingga dewasa, dengan karakteristik seperti bentuk sungguhan dan dibuat seperti prototype, dan bentuknya yang klasik tidak seperti mainan-mainan seperti model sekarang. Tetapi selain dari kekuatan desain ini ada kelemahan salah satunya adalah dimaikan dengan cara manual karena tidak seperti mainan yang didesain berjalan otomatis ketika ada batrenya. Peluang dari pemilihan desain ini adalah bahan baku mudah didapat dengan memanfaatkan kayu bekas dalam membuat mainan. Untuk ancamanya dalam pemilihan desain ini adalah pengrajin pembuatan mainan akan bermunculan karena sangat mudah dicontoh dan mudah dalam proses pembuatanya.

\section{DAFTAR PUSTAKA}

Blanchard, B. S., Fabrycky, W. J., \& Fabrycky, W. J. (1990). Systems engineering and analysis (Vol. 4). Englewood Cliffs, NJ: Prentice Hall.

Cross, N. (2011). Design thinking: Understanding how designers think and work. Berg.

Ginting, R. (2009). Perancangan Produk. Yogyakarta: Graha Ilmu.

Holtzapple. 2011. Concepts in Engineering:

Pengantar Dasar Teknologi). Jakarta:

Kencana Prenada Media Group.

Hill, T., \& Westbrook, R. (1997). SWOT analysis: it's time for a product recall. Long range planning, 30(1), 46-52.

Hurst, K. (2006). Prinsip-Prinsip Perancangan Teknik. Jakarta: Erlangga.

Kim, K. J., Moskowitz, H., Dhingra, A., \& Evans, G. (2000). Fuzzy multicriteria models for quality function deployment. European Journal of Operational Research, 121(3), 504-518

Rangkuti F, (2011). "SWOT Balanced Scorecard", PT Gramedia Pustaka Utama, Jakarta. 
Sulaiman F, (2017). "Desain Produk Rancangan Tempat Lilin Multi FungsiMenggunkana Pendekatan 7 Langkah Nigel Cross" Jurnal Teknovasi, Politeknik LP31 Medan. 